\title{
Climatic effects of 1950-2050 changes in US anthropogenic aerosols - Part 2: Climate response
}

\author{
E. M. Leibensperger ${ }^{1, *}$, L. J. Mickley ${ }^{1}$, D. J. Jacob ${ }^{1}$, W.-T. Chen ${ }^{2}$, J. H. Seinfeld ${ }^{3}$, A. Nenes ${ }^{4}$, P. J. Adams ${ }^{5}$, \\ D. G. Streets ${ }^{6}$, N. Kumar ${ }^{7}$, and D. Rind ${ }^{8}$ \\ ${ }^{1}$ School of Engineering and Applied Sciences, Harvard University, Cambridge, MA, USA \\ ${ }^{2}$ Jet Propulsion Laboratory, California Institute of Technology, Pasadena, CA, USA \\ ${ }^{3}$ Division of Chemistry and Chemical Engineering, California Institute of Technology, Pasadena, CA, USA \\ ${ }^{4}$ School of Earth \& Atmospheric Sciences and School of Chemical \& Biological Engineering, Georgia Institute of \\ Technology, Atlanta, GA, USA \\ ${ }^{5}$ Department of Civil \& Environmental Engineering and Department of Engineering \& Public Policy, Carnegie Mellon \\ University, Pittsburgh, PA, USA \\ ${ }^{6}$ Argonne National Laboratory, Argonne, IL, USA \\ ${ }^{7}$ Electric Power Research Institute, Palo Alto, CA, USA \\ ${ }^{8}$ NASA Goddard Institute for Space Studies, New York, NY, USA \\ *now at: Dept. of Earth, Atmospheric and Planetary Sciences, Massachusetts Institute of Technology, Cambridge, MA, USA
}

Correspondence to: E. M. Leibensperger (eleibens@mit.edu)

Received: 20 May 2011 - Published in Atmos. Chem. Phys. Discuss.: 29 August 2011

Revised: 14 December 2011 - Accepted: 22 February 2012 - Published: 10 April 2012

\begin{abstract}
We investigate the climate response to changing US anthropogenic aerosol sources over the 1950-2050 period by using the NASA GISS general circulation model (GCM) and comparing to observed US temperature trends. Time-dependent aerosol distributions are generated from the GEOS-Chem chemical transport model applied to historical emission inventories and future projections. Radiative forcing from US anthropogenic aerosols peaked in 1970-1990 and has strongly declined since due to air quality regulations. We find that the regional radiative forcing from US anthropogenic aerosols elicits a strong regional climate response, cooling the central and eastern US by $0.5-1.0^{\circ} \mathrm{C}$ on average during 1970-1990, with the strongest effects on maximum daytime temperatures in summer and autumn. Aerosol cooling reflects comparable contributions from direct and indirect (cloud-mediated) radiative effects. Absorbing aerosol (mainly black carbon) has negligible warming effect. Aerosol cooling reduces surface evaporation and thus decreases precipitation along the US east coast, but also increases the southerly flow of moisture from the Gulf of Mexico resulting in increased cloud cover and precipitation in the central US. Observations over the eastern US show a lack of warming in 1960-1980 followed by very rapid warming since, which we reproduce in the GCM and attribute to trends
\end{abstract}

in US anthropogenic aerosol sources. Present US aerosol concentrations are sufficiently low that future air quality improvements are projected to cause little further warming in the US $\left(0.1^{\circ} \mathrm{C}\right.$ over $\left.2010-2050\right)$. We find that most of the warming from aerosol source controls in the US has already been realized over the 1980-2010 period.

\section{Introduction}

Global mean surface temperatures increased by $0.74 \pm 0.18^{\circ} \mathrm{C}$ between 1906 and 2005 due to increasing greenhouse gases (Trenberth et al., 2007). However, temperature trends on regional scales are more complicated. For example, the eastern US experienced a cooling between 1930 and 1990 (Fig. 1). The net cooling effect of anthropogenic aerosols is known to have mitigated some of the global warming from greenhouse gases (Hegerl et al., 2007), but the importance of aerosol cooling on temperature trends in the US has received little attention. As US aerosol sources are increasingly controlled to improve air quality, the associated cooling is undone resulting in accelerated warming (Andreae et al., 2005; Brasseur and Roeckner, 2005; Kloster et al., 2009; Mickley et al., 2012). Air quality 


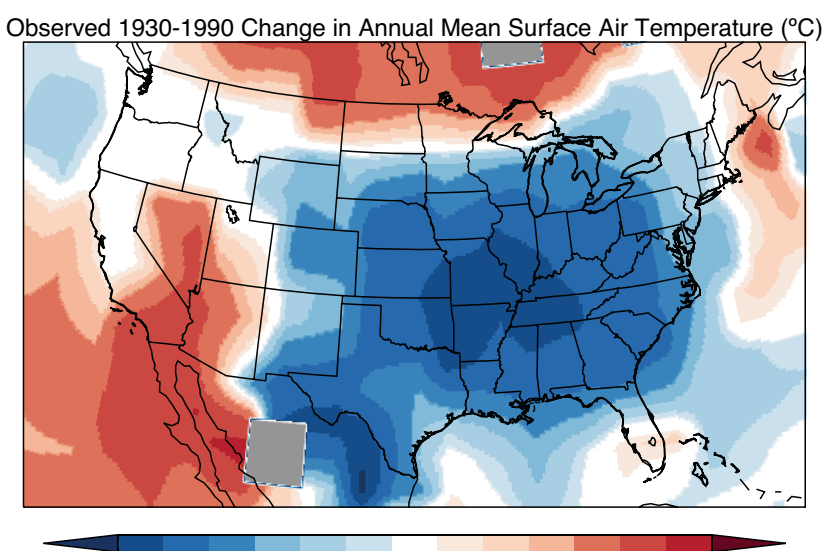

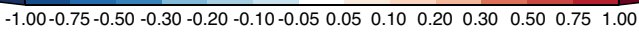

Fig. 1. Observed change in surface air temperature between 1930 and 1990. Temperature change is based on the linear trend as in Hansen et al. (2001). Observations are from the NASA GISS Surface Temperature Analysis (GISTEMP; http://data.giss.nasa.gov/ gistemp/).

improvement thus comes with climate consequences (Raes and Seinfeld, 2009). In Leibensperger et al. (2012), we reconstructed and projected the aerosol trends and associated radiative forcing from US anthropogenic sources over the 1950-2050 period. US aerosol concentrations peaked in 1970-1990 and have decreased rapidly since. We use here a general circulation model (GCM) to study the associated climate response.

Anthropogenic aerosols directly affect the climate system by scattering and absorbing solar radiation, and indirectly by altering cloud microphysical properties. Aerosol scattering cools and absorption warms the atmosphere, but both cause a reduction in surface solar radiation. Observations of surface solar radiation over the US show a widespread decrease over the 1950-1990 period followed by a more recent increase (Liepert and Tegen, 2002; Long et al., 2009). These trends have been identified in clear and all-sky scenes, suggesting a role for both direct and indirect aerosol effects. These trends in surface solar radiation are qualitatively consistent with changes in aerosol sources (Streets et al., 2009), but cannot be entirely explained by anthropogenic aerosols (Liepert and Tegen, 2002; Long et al., 2009; Wild, 2009b; Koch et al., 2011).

Aerosols are scavenged from the atmosphere by precipitation on a time scale of days, so that their radiative forcing is strongly localized over source regions (Schulz et al., 2006). A critical issue is whether the regional radiative forcing of aerosols elicits a correspondingly regional climate response. Observation-based studies have related changes in surface solar radiation with other climate variables as a method of deducing the local effects of aerosol forcing. They show evidence that aerosols have lowered surface air temperature and temporarily offset greenhouse warming (Qian and Giorgi,
2000; Wild et al., 2007; Ruckstuhl et al., 2008; Philipona et al., 2009), reduced the diurnal temperature range by dampening daily maximum temperatures (Liu et al., 2004b; Wild et al., 2007; Makowski et al., 2009), lowered evaporation rates (Peterson et al., 1995; Liu et al., 2004a; Roderick et al., 2007), and increased soil moisture (Robock et al., 2005).

Some GCM studies have found strong regional climate sensitivity to aerosols including in India (Menon et al., 2002; Wang et al., 2009a), southeast Asia (Chang et al., 2009; Zhang et al., 2011; Lee and Kim, 2010), the North Atlantic (Fischer-Bruns et al., 2009), and the western US (Jacobson, 2008). However, other studies have found that the climate response to aerosol radiative forcing is more hemispheric or global in scale with patterns similar (but opposite in sign) to greenhouse gas forcing (Mitchell et al., 1995; Shindell et al., 2007, 2008; Levy et al., 2008; Kloster et al., 2009). Shindell et al. (2010) estimated the spatial extent of the climate response to aerosol radiative forcing in four GCMs and found it to extend $\sim 3500 \mathrm{~km}$ in the meridional direction and $\sim 12000 \mathrm{~km}$ in the zonal direction. FischerBruns et al. (2010) investigated the climate impacts of removing North American aerosols and found a $1.0-1.5^{\circ} \mathrm{C}$ summer warming in surface air over the US and North Atlantic Ocean. They also found a $1.5-2.0^{\circ} \mathrm{C}$ warming of the Arctic in winter. However, Mickley et al. (2012) simulated the climate response of completely removing aerosols over the US and found a $0.4-0.6^{\circ} \mathrm{C}$ regional warming in the US with little effect elsewhere.

There is strong motivation for air quality agencies to decrease aerosol concentrations to improve public health. Better understanding of the associated climate response is necessary. The US is of particular interest in this regard because aerosol concentrations rose in the 20th century, peaked in the 1980s, and have been decreasing rapidly since due in large part to a $56 \%$ reduction of $\mathrm{SO}_{2}$ emissions between 1980 and 2008 (US EPA, 2010). Here we use the 1950-2050 time series of US aerosol concentrations from Leibensperger et al. (2012) to conduct 1950-2050 transient climate simulations with the NASA Goddard Institute for Space Studies (GISS) GCM 3 (Rind et al., 2007). Our objective is to investigate the regional climate effects of historical and projected changes in US anthropogenic aerosol sources. An important advance compared to previous work is the use of a realistic evolution of aerosol sources.

\section{Methods}

We conduct sensitivity simulations with the GISS GCM 3 to study the evolving 1950-2050 climate response to changing US anthropogenic aerosol sources. The GCM uses archived global 3-D monthly mean concentrations of different aerosol components from the GEOS-Chem chemical transport model (CTM) with time-dependent emissions based on historical data and future projections. The CTM 
simulations are described by Leibensperger et al. (2012) and a brief summary is given below.

\subsection{Aerosol simulations}

We conduct a 2-yr GEOS-Chem simulation of coupled ozone- $\mathrm{NO}_{\mathrm{x}}$-VOC-aerosol chemistry (http://geos-chem.org; Bey et al., 2001; Park et al., 2004) for each decade between 1950 and 2050. The first year is used as model initialization. Monthly mean fine aerosol concentrations are archived from the second year for use in the GCM including sulfatenitrate-ammonium (SNA), primary organic aerosol (POA), secondary organic aerosol (SOA), and black carbon (BC) (Park et al., 2006; Liao et al., 2007). Simulations for all years use the same assimilated meteorological data from 20002001 so that changes in concentrations over the 1950-2050 period are due to emissions only. The meteorological data are from the NASA Goddard Earth Observing System (GEOS)-4 with $1^{\circ} \times 1.25^{\circ}$ horizontal resolution, 55 vertical levels, and 6-h temporal resolution (3-h for surface variables and mixing depths). The horizontal resolution is degraded to $2^{\circ} \times 2.5^{\circ}$ for input to GEOS-Chem. The effect of US anthropogenic sources is determined by parallel sensitivity simulations for the 1950-2050 period with zero US anthropogenic emissions of $\mathrm{SO}_{2}, \mathrm{NO}_{\mathrm{x}}, \mathrm{POA}$, and $\mathrm{BC}$. "Anthropogenic" here includes fuel and industrial sources but not open fires.

We use 1950-1990 global anthropogenic emissions of $\mathrm{SO}_{2}$ and $\mathrm{NO}_{\mathrm{x}}$ from EDGAR Hyde 1.3 (van Aardenne et al., 2001) and 2000 emissions from EDGAR 3.2 FT (Olivier and Berdowski, 2001). Historical emissions of BC and POA are from Bond et al. (2007). Emissions past 2000 are calculated using growth factors derived from the Integrated Model to Assess the Greenhouse Effect (IMAGE; Streets et al., 2004) following the IPCC A1B scenario (Nakićenović and Swart, 2000). As in Fiore et al. (2002) and Wu et al. (2008), growth factors are calculated for different countries and fuel types (fossil fuel and biofuel). Ammonia emissions are from Bouwman et al. (1997) as modified by Park et al. (2004), except for East Asia (Streets et al., 2003). Additional sources include climatological biomass burning (Duncan et al., 2003), fertilizer (Wang et al., 1998), aircraft (Chin et al., 2000), the biosphere, volcanoes, and lightning. See Leibensperger et al. (2012) for more detail.

\subsection{Climate simulations}

We conduct transient climate simulations with the GISS GCM 3 using a horizontal resolution of $4^{\circ} \times 5^{\circ}$ and 23 vertical levels that extend from the surface to $0.002 \mathrm{hPa}$. GISS GCM 3 shares a common history with another NASA GISS GCM, Model E (Schmidt et al., 2006), but the two differ in their parameterizations of gravity wave drag, convection, and the boundary layer (Rind et al., 2007). GISS GCM 3 has been previously used in studies investigating air quality-climate interactions (Leibensperger et al., 2008; Wu et al., 2008; Pye et al., 2009; Chen et al., 2010b; Mickley et al., 2012), tracer transport (Rind et al., 2007), climate response to solar forcing (Rind et al., 2008), and stratospheric ozone-climate interactions (Rind et al., 2009a, b). The model contains a Qflux ocean, in which monthly oceanic heat transports are held constant but sea surface temperature and sea ice coverage are allowed to respond to energy exchange with the atmosphere (Hansen et al., 1988). We calculate ocean heat transport using equilibrium climate simulations forced with observed sea surface temperature (SST) and sea ice distributions for 19461955 (Rayner et al., 2003), following the method outlined by Hansen et al. (1988).

To compute the aerosol direct effect, we import 3-D monthly mean aerosol concentrations archived from GEOSChem. Concentrations are interpolated between decadal time slices. Aerosol optical properties are calculated assuming an internal mixture. Following Chung and Seinfeld (2002) and Liao et al. (2004), we assume a standard gamma aerosol size distribution with an effective dry radius of $0.3 \mu \mathrm{m}$ and areaweighted variance of 0.2 . Optical properties of the internal mixture are calculated using the volume-weighted mean of the refractive indices of the individual components. The resulting direct forcing from US anthropogenic aerosol sources in 1980 (peak aerosol loading) is only $-0.07 \mathrm{~W} \mathrm{~m}^{-2}$ globally but $-2.0 \mathrm{~W} \mathrm{~m}^{-2}$ over the eastern US (Leibensperger et al., 2012). Dust and sea salt aerosols are considered externally mixed and held constant for 1950-2050 at the climatological radiative forcing values of Hansen et al. (2002).

Aerosol indirect radiative effects are computed following the approach previously implemented by Chen et al. (2010b) in the GISS GCM 3. This includes the first indirect effect (cloud albedo) and the second indirect effect (cloud lifetime), both on liquid stratiform clouds only. Aerosol mass concentrations affect the cloud droplet number concentration $N_{\mathrm{c}}$ $\left(\mathrm{m}^{-3}\right)$, which in turn determines the effective radius of cloud droplets and the rate of autoconversion to precipitation. We calculate $N_{\mathrm{c}}$ from the archived GEOS-Chem aerosol mass distributions using the method of Chen et al. (2010b):

$\log N_{\mathrm{c}}=A+B \log m_{\mathrm{i}}$

where $m_{\mathrm{i}}$ is the molar concentration of dissolved aerosol ions $\left(\mathrm{mol} \mathrm{m}^{-3}\right)$ and $A$ and $B$ are gridded 3-D monthly mean coefficients derived from detailed simulations of aerosol microphysics and activation within the GCM (Adams and Seinfeld, 2002; Nenes and Seinfeld, 2003; Fountoukis and Nenes, 2005; Pierce and Adams, 2006). Cloud optical depth scales as the inverse of the area-weighted mean effective radius $r_{\mathrm{e}}$ of the cloud droplet size distribution (Del Genio et al., 1996). We obtain $r_{\mathrm{e}}$ from:

$r_{\mathrm{e}}=\kappa^{-\frac{1}{3}}\left[\frac{3 L}{4 \pi N_{\mathrm{c}}}\right]^{\frac{1}{3}}$

where $L$ is the liquid water content of the cloud $\left(\mathrm{cm}^{3}\right.$ water per $\mathrm{cm}^{-3}$ air), and $\kappa$ is a constant ( 0.67 over land, 0.80 over 
ocean; Martin et al., 1994) that relates the volume-weighted and area-weighted mean radii. Autoconversion rates are calculated using the parameterization of Khairoutdinov and Kogan (2000), which fits results from an explicit microphysical model:

$$
\frac{\mathrm{d} q_{1}}{\mathrm{~d} t}=-1350 \gamma q_{1}^{2.47} N_{\mathrm{c}}^{-1.79}
$$

where $q_{1}$ is the cloudwater mass content $\left(\mathrm{kg} \mathrm{kg}^{-1}\right)$. Hoose et al. (2008) and Chen et al. (2010b) added the tuning parameter $\gamma$ in order to retain GCM climate equilibrium. We find that a $\gamma$ value of 12 retains top-of-atmosphere (TOA) radiative balance in a climate equilibrium simulation for 1950 conditions including fixed SST and sea ice (Leibensperger et al., 2012). $\gamma=12$ is consistent with the recent results of Morales and Nenes (2010), who found that autoconversion rates can be underestimated by a factor of 2 to 10 when models use gridbox-scale values of $N_{\mathrm{c}}$.

Two sets of control simulations were conducted. The first includes only the direct radiative forcing from aerosols, using the imported aerosol concentrations from GEOS-Chem. The second additionally imports $N_{\mathrm{c}}$ as calculated in Eq. (1) to account for the aerosol indirect effects. Sensitivity simulations were conducted relative to each of these controls using the aerosol and $N_{\mathrm{c}}$ fields from the GEOS-Chem simulations with US anthropogenic sources of $\mathrm{SO}_{2}, \mathrm{NO}_{\mathrm{x}}, \mathrm{POA}$, and $\mathrm{BC}$ shut off. Differences between the control and sensitivity simulations then measure the climate response to US anthropogenic sources through the direct and indirect effects of aerosols.

Each set of simulations consists of a five-member ensemble conducted from 1950 to 2050 using the trends in natural and greenhouse gas forcing described by Hansen et al. (2002). Future greenhouse gas concentrations follow the IPCC SRES A1B scenario with $\mathrm{CO}_{2}, \mathrm{~N}_{2} \mathrm{O}$, and $\mathrm{CH}_{4}$ reaching 522, 0.350 , and $2.40 \mathrm{ppm}$, respectively, by 2050 . The A1B scenario provides a radiative forcing for the 21 st century comparable to the more recent RCP6 scenario from the IPCC (Moss et al., 2010). Initiating climate simulations from 1950 equilibrium conditions neglects the small radiative imbalance that occurred at that time. A previous study with the GISS GCM using the same climate forcing as here (except for tropospheric aerosols) found the Earth to be out of radiative balance by $+0.18 \mathrm{~W} \mathrm{~m}^{-2}$ for 1951 conditions (Sun and Hansen, 2003). This suggests that our simulations underestimate post- 1950 global warming by approximately $0.1^{\circ} \mathrm{C}$, a small effect that does not impact our assessment of the climate response to US anthropogenic aerosols since it is common to both the control and sensitivity simulations.

We conducted an additional sensitivity simulation to isolate the climate effects of US anthropogenic sources of BC. This simulation uses the sulfate, nitrate, POA, and SOA distributions from the control simulation, but no $\mathrm{BC}$ emission from US anthropogenic sources. Results indicate that the climate effects of US anthropogenic BC are small and indistinguishable from interannual variability. This is consistent with the weak radiative forcing from US anthropogenic BC $\left(+0.02 \mathrm{~W} \mathrm{~m}^{-2}\right.$ globally and $+0.4 \mathrm{~W} \mathrm{~m}^{-2}$ over the eastern US for 1970-1990; Leibensperger et al., 2012). More generally, we find that a regional radiative forcing of about $1.0 \mathrm{~W} \mathrm{~m}^{-2}$ is necessary to produce a climate response greater than natural variability in the GISS GCM 3 with a 5-member ensemble. The climate effects of $\mathrm{BC}$ may differ when considering co-emitted species and microphysical effects (Bauer et al., 2010; Chen et al., 2010a; Jacobson, 2010). The climate effects of $\mathrm{BC}$ are additionally sensitive to the vertical profile of BC and modeled cloud cover (Koch and Del Genio, 2010). Koch et al. (2011) found surface air temperature to be less sensitive to $\mathrm{BC}$ than a similar amount of sulfate radiative forcing due to compensating changes in stability and cloud cover. Previous studies have shown a significant climate response in Asia where BC radiative forcing is greater (Menon et al., 2002; Wang et al., 2009a), but this region has larger $\mathrm{BC}$ emissions. We do not discuss this simulation further.

The use of archived monthly mean aerosol distributions as input to our climate simulations does not allow for feedbacks of changing climate on aerosol concentrations. These feedbacks are likely very small relative to the source driven aerosol perturbations implemented here, considering that both models and observations indicate little direct sensitivity of aerosol air quality to climate change (Jacob and Winner, 2009; Tai et al., 2011). The use of monthly mean aerosol concentrations does not introduce significant bias in the calculation of the direct radiative effect (Koch et al., 1999), but it may affect the aerosol indirect effect due to the nonlinear relationship between aerosol amount and cloud droplet number (Jones et al., 2001) as seen in Eq. (1).

We test the statistical significance of all our results using a modified version of Student's t-test to account for serial correlation (Zwiers and von Storch, 1995). Results presented here are significant at the 95th percentile and represent the mean of ensemble members unless specified.

\section{Climate response to US anthropogenic aerosols}

\subsection{Radiation}

Figure 2 shows the annual mean change in net TOA and surface solar radiation due to the direct and indirect radiative effects of US anthropogenic aerosols in 1970-1990, the period when US aerosol loadings were at their peak. These differ from the radiative forcings reported by Leibensperger et al. (2012) in that they include the effects of climate response, such as changes in cloud cover. We find that the radiative effect is strongly concentrated over the eastern US, and define a mid-Atlantic US region boxed in Fig. 2 where the effect is maximum. The annual mean TOA radiative effect averages $-6 \mathrm{~W} \mathrm{~m}^{-2}$ over that region, whereas the global TOA radiative effect is only $-0.08 \mathrm{~W} \mathrm{~m}^{-2}$. 


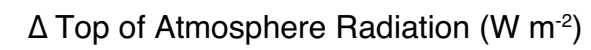

\section{$\Delta$ Surface Solar Radiation $\left(\mathrm{W} \mathrm{m}^{-2}\right)$}
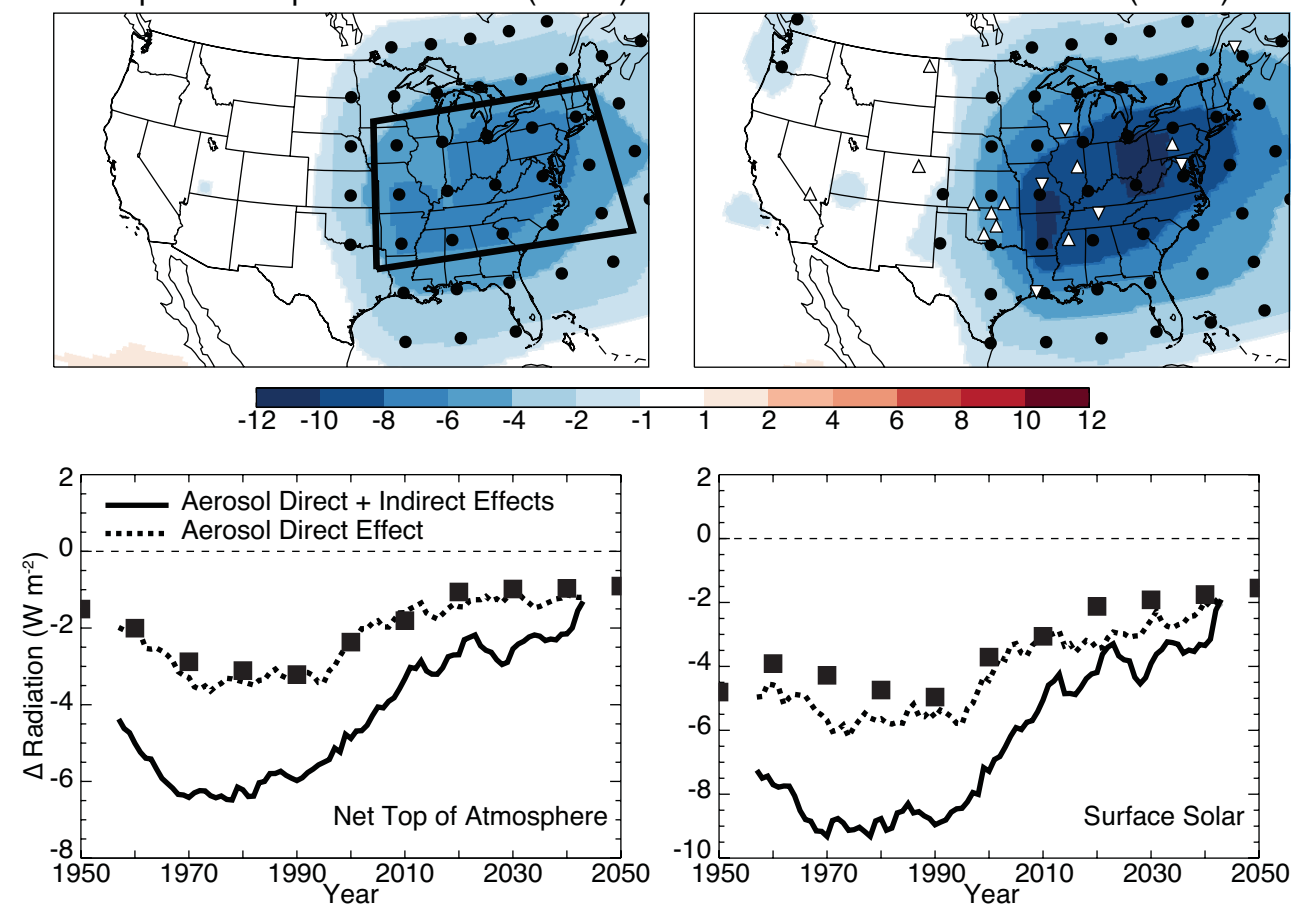

Fig. 2. Changes in net top-of-atmosphere (TOA) radiation (left) and surface solar radiation (right) due to US anthropogenic aerosol sources. The top panels show the annual mean aerosol effect (direct and indirect) averaged over 1970-1990. The bottom panels show the 1950-2050 evolution of the direct effect only (dashed) and the sum of direct and indirect effects (solid) averaged over the mid-Atlantic US (boxed region). Values are differences between the control simulation and a simulation with US anthropogenic aerosol sources shut off. In the top panels, dots indicate differences significant at the 95th percentile, downward triangles indicate observation sites used by Liepert and Tegen (2002), and upward triangles indicate observation sites used by Long et al. (2009). In the lower panels, black squares indicate the annual mean aerosol direct radiative forcings over the mid-Atlantic US region from US anthropogenic sources calculated by Leibensperger et al. (2012). Time series have been filtered by a 15-yr moving average.

The bottom panels of Fig. 2 show the 1950-2050 time series of the TOA and surface radiative effects from US anthropogenic aerosol sources over the mid-Atlantic region. Results are shown for the direct effect only and for the sum of direct and indirect effects. The magnitudes and trends of the direct effect match closely the corresponding instantaneous radiative forcings computed in Leibensperger et al. (2012) (squares in Fig. 2). The indirect effect is comparable in magnitude to the direct effect. Sulfate is the largest contributor to US anthropogenic aerosol forcing (Leibensperger et al., 2012). We see from Fig. 2 that the radiative perturbations largely follow the evolution of $\mathrm{SO}_{2}$ sources: increase until 1980 and rapid decrease afterward. Changes level off after 2020 , by which time $\mathrm{SO}_{2}$ emissions are $80 \%$ lower than their 1980 peak.

The surface radiative effects in Fig. 2 are about $50 \%$ larger than the TOA effects due to aerosol absorption. Liepert and Tegen (2002) used six observation sites east of $95^{\circ} \mathrm{W}$ (downward triangles in Fig. 1) from the National Solar Radiation Database (NSRDB; http://rredc.nrel.gov/solar/old_data/ $\mathrm{nsrdb} /$ ) to estimate a clear-sky trend in surface solar radi- ation of $-7 \mathrm{~W} \mathrm{~m}^{-2}$ between 1961 and 1990 that they attributed to the aerosol direct effect. Long et al. (2009) calculated an observed 1996-2007 increase in surface solar radiation of $+5 \mathrm{~W} \mathrm{~m}^{-2}$ (clear sky) and $+8 \mathrm{~W} \mathrm{~m}^{-2}$ (all sky) averaged over 11 Department of Energy Atmospheric Radiation Measurement (ARM) and National Oceanic and Atmospheric Administration (NOAA) US Surface Radiation Budget (SURFRAD) sites (upward triangles in Fig. 2). However, and as previously noted (Liepert and Tegen, 2002; Long et al., 2009; Wild, 2009a, b; Koch et al., 2011), we find that anthropogenic aerosols cannot explain the magnitude of the observed surface radiation trends. Sampling our control simulation at the six sites analyzed by Liepert and Tegen (2002), we find a simulated all-sky decrease of surface solar radiation of $1.1 \mathrm{~W} \mathrm{~m}^{-2}$ between 1961 and 1990 due to the aerosol direct effect, much smaller than the observed value. Conversion of our all-sky trend to the clear-sky value would not reconcile the difference. Similarly, our control simulation underestimates the 1996-2007 all-sky increase of Long et al. (2009) $\left(+2.4 \mathrm{~W} \mathrm{~m}^{-2}\right.$ vs. $\left.+8 \mathrm{~W} \mathrm{~m}^{-2}\right)$. 
We previously showed that our simulated trend of sulfate over the US is in good agreement with observations, at least for 1990-present, while the simulated decreasing trend of black carbon is too low by a factor of 2 (Leibensperger et al., 2012). Correcting for this discrepancy does not reconcile the simulated and observed 1996-2007 trends in solar radiation. The observed surface solar radiation trends remain larger than our simulated trends and thus seem much larger than can be explained from aerosol trends. The discrepancy seems unlikely to arise from underestimated aerosol radiative effects since models consistently underestimate the observed trend (Liepert and Tegen, 2002; Long et al., 2009; Wild, 2009a, b; Koch et al., 2011). The 1961-1990 NSRDB surface solar radiation data suffer from inconsistent data quality, but the more recent measurements presented by Long et al. (2009) have consistent annual calibration and daily performance monitoring. The cause of the model-observation discrepancy is unclear but suggests that observed trends in surface radiation are not driven solely by aerosols.

\subsection{Temperature}

Figure 3 shows the annual mean temperature changes in surface air and at $500 \mathrm{hPa}$ due to the direct and indirect effects of US anthropogenic aerosol sources over the 1970-1990 period when US anthropogenic aerosol forcing was at its peak. Changes in surface air temperature are largest in the eastern US $\left(0.5-1.0^{\circ} \mathrm{C}\right.$ cooling), collocated with the maximum radiative effect (Fig. 2). The cooling influence of US anthropogenic aerosols extends over much of the Northern Hemisphere, but beyond the US and North Atlantic Ocean it is only marginally significant against modeled interannual variability. The annual mean cooling averages $0.1^{\circ} \mathrm{C}$ for the Northern Hemisphere and $0.05^{\circ} \mathrm{C}$ for the Southern Hemisphere.

We find that the cooling effect of US anthropogenic aerosols is largely confined to the US and North Atlantic. As pointed out in the Introduction, Shindell et al. (2010) estimated the spatial extent of the climate response to aerosol radiative forcing to span $\sim 3500 \mathrm{~km}$ in the meridional direction and $\sim 12000 \mathrm{~km}$ in the zonal direction. We find in our simulation that some cooling from US anthropogenic aerosols extends to these distances but is only marginally significant or insignificant. The cooling within the US caused by US anthropogenic aerosols shown in Fig. 3 is not apparent in the simulations of Shindell et al. (2010), which simulated the climate response of all anthropogenic aerosols. However, cooling within the US can be found in other simulations of the climate effects of anthropogenic aerosols (Mitchell et al., 1995; Hansen et al., 2005; Wilcox et al., 2009; Mickley et al., 2012).

Cooling is more diffuse at higher altitudes, reflecting the faster transport of heat (Fig. 3, top). At $500 \mathrm{hPa}$, the largest cooling is $0.3^{\circ} \mathrm{C}$ over the eastern US and North Atlantic Ocean. Statistically significant cooling covers more of the

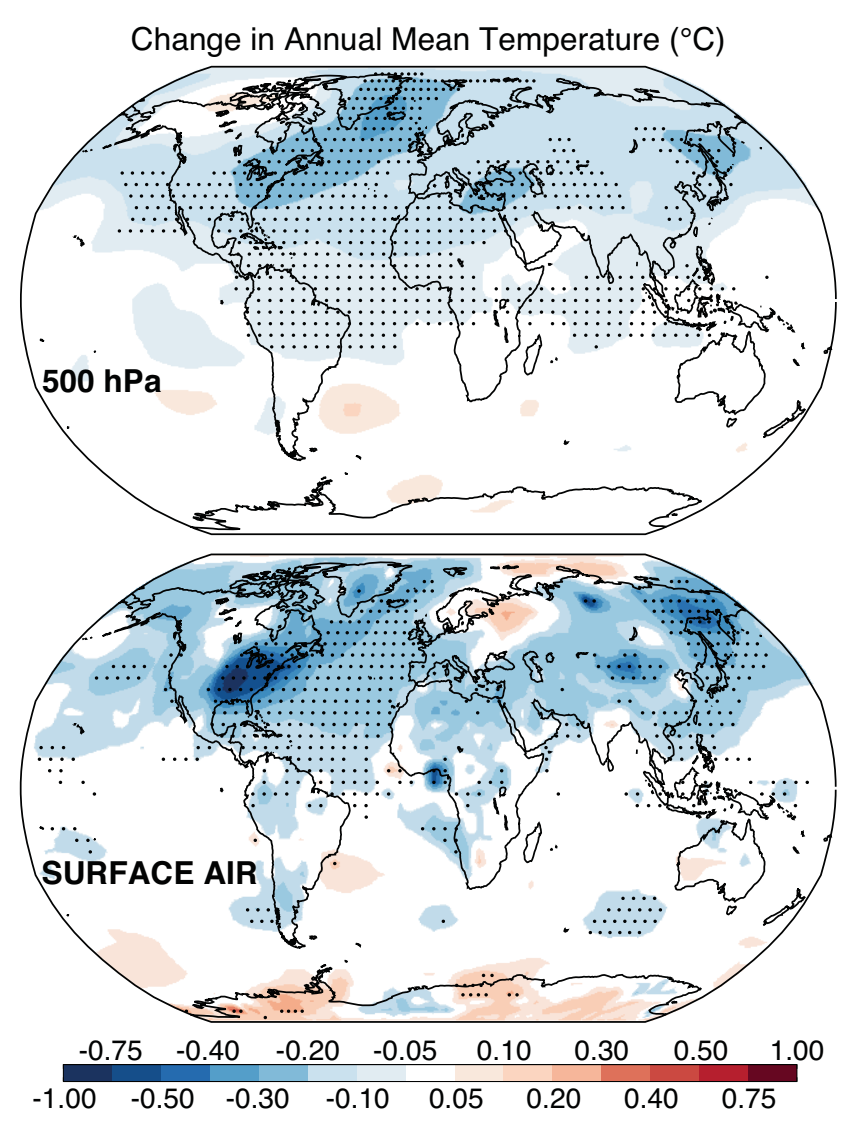

Fig. 3. Effect of US anthropogenic aerosol sources on annual mean temperatures $\left({ }^{\circ} \mathrm{C}\right.$ ) for the $1970-1990$ period (when US aerosol loading was at its peak). Values are shown for surface air (bottom) and $500 \mathrm{hPa}$ (top) temperatures. They represent the mean difference between 5-member ensemble GCM simulations including vs. excluding US anthropogenic aerosol sources, and considering both aerosol direct and indirect effects. Dots indicate differences significant at the 95 th percentile.

Northern Hemisphere at $500 \mathrm{hPa}$ than at the surface. Annual mean cooling at $500 \mathrm{hPa}$ averages $0.1^{\circ} \mathrm{C}$ for the Northern Hemisphere and $0.02^{\circ} \mathrm{C}$ for the Southern Hemisphere, similar to the hemispheric changes in surface air temperature. Cooling is even more diffuse at $300 \mathrm{hPa}$ (not shown), but Northern Hemisphere cooling is similarly $0.1^{\circ} \mathrm{C}$.

Figure 4 shows the surface air cooling over the US due to US anthropogenic aerosols for the 1970-1990 period for the simulations including only the aerosol direct effect (top) and the combination of direct and indirect effects (bottom). The bottom panel is a zoomed version of the bottom panel of Fig. 3. Significant cooling extends over much of the US even when the aerosol direct effect alone is considered. The magnitude of the cooling doubles when the indirect effects are included but the spatial patterns are similar. Thus the significance and localization of the US cooling due to US anthropogenic aerosol sources is not contingent on the indirect effects, which are far more uncertain than the direct effect. 
Change in Annual Mean Surface Air Temperature $\left({ }^{\circ} \mathrm{C}\right)$

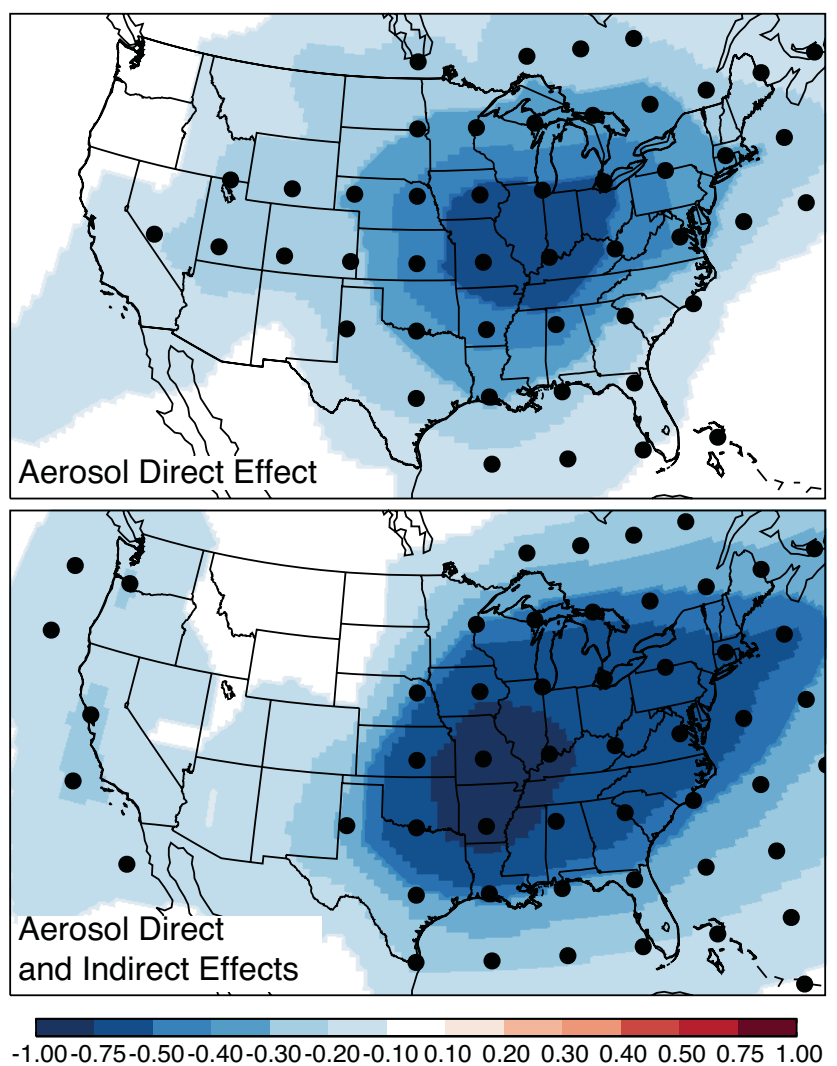

Fig. 4. Effect of US anthropogenic aerosol sources on surface air temperatures for the 1970-1990 period when US aerosol loading was at its peak. Values represent the mean difference between 5member ensemble GCM simulations including vs. excluding US anthropogenic aerosol sources, and considering the aerosol direct only (top) and the sum of direct and indirect effects (bottom). Dots indicate differences significant at the 95 th percentile. The bottom panel contains the same information as the bottom panel of Fig. 3 but zoomed over the US.

Cooling is strongest in the Midwest, shifted westward relative to the surface and TOA radiative effects shown in Fig. 2. This is due to hydrological factors and is discussed further in Sect. 3.3.

Figure 5 shows seasonal statistics of the effects of US anthropogenic aerosols on surface air temperatures in the midAtlantic US (boxed region in Fig. 2). The change in surface air temperature is largest in summer and autumn, with regionally averaged cooling of more than $1.0^{\circ} \mathrm{C}$ in autumn. Aerosol radiative forcing is largest in summer when solar radiation is strongest. The larger surface air temperature changes in autumn reflect the drier conditions typical of that time of year, so that less of the radiative effect is buffered by changes in surface evaporation (latent heat flux).

Figure 5 also presents the changes in extreme temperatures. We find that aerosol cooling has a larger effect on

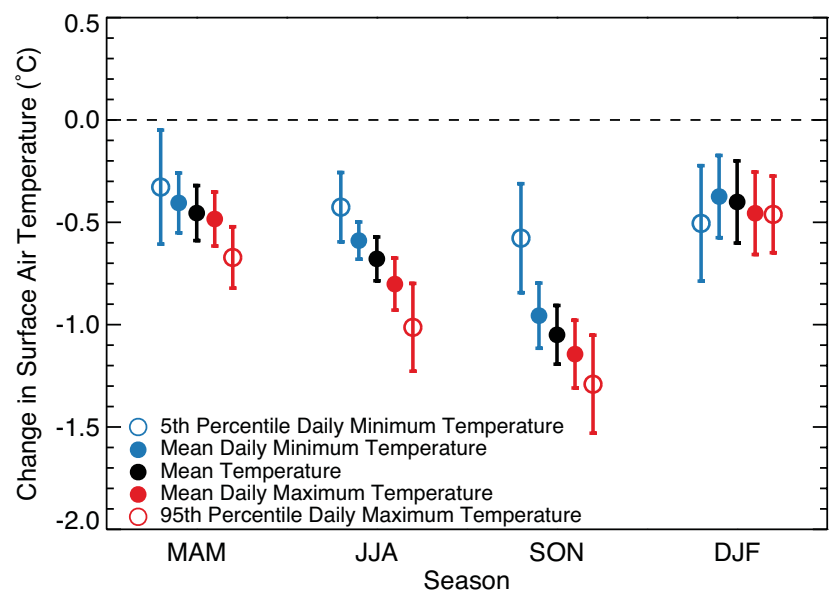

Fig. 5. Effect of US anthropogenic aerosols on seasonal surface air temperature statistics over the mid-Atlantic US (boxed region in Fig. 2). Values are for 1970-1990, when US aerosol loads were at their peak. Statistics were obtained by difference between 5member ensemble GCM simulations including vs. excluding US anthropogenic aerosol sources, and considering both the aerosol direct and indirect effects. Error bars indicate $95 \%$ confidence intervals.

daily maximum than daily minimum temperatures, in all seasons, as expected since the forcing is due to scattering of solar radiation. The cooling is largest during heat waves of summer and autumn (95th percentile daily maximum temperatures, corresponding to the 5 hottest days of each season). These heat waves occur under cloud free conditions when the aerosol direct effect is especially effective. We find that the warmest days are cooler by $1.0^{\circ} \mathrm{C}$ in summer and $1.3^{\circ} \mathrm{C}$ in autumn. The coldest nights of each season (5th percentile daily minimum temperatures) are least sensitive to aerosols except in winter when they are typically associated with synoptic-scale clear-sky conditions.

The model pattern of aerosol-driven cooling over the US in Fig. 4 is remarkably similar to the observed pattern in the 1930-1990 trend in surface air temperature shown in Fig. 1. The largest area of cooling in the central US has previously been referred to as a "warming hole" (Pan et al., 2004; Kunkel et al., 2006). Previous GCM studies have associated this warming hole with variations in SSTs in the tropical Pacific (Robinson et al., 2002; Kunkel et al., 2006; Wang et al., 2009b). Kunkel et al. (2006) additionally point out a strong association between the observed variability of North Atlantic SSTs and central US surface temperatures. Our results indicate that the warming hole could be due to US anthropogenic aerosols, as $\mathrm{SO}_{2}$ anthropogenic emissions in 1930 were only $60 \%$ of those in 1980 . We find that US anthropogenic aerosols lower SSTs in the North Atlantic region outlined by Kunkel et al. (2006) by up to $-0.3^{\circ} \mathrm{C}$. Lower SSTs over the North Atlantic enhance the anticyclonic transport of marine air over the Gulf Coast of the US, magnifying the cooling as discussed below. 
a) Evaporation (mm day ${ }^{-1}$ )

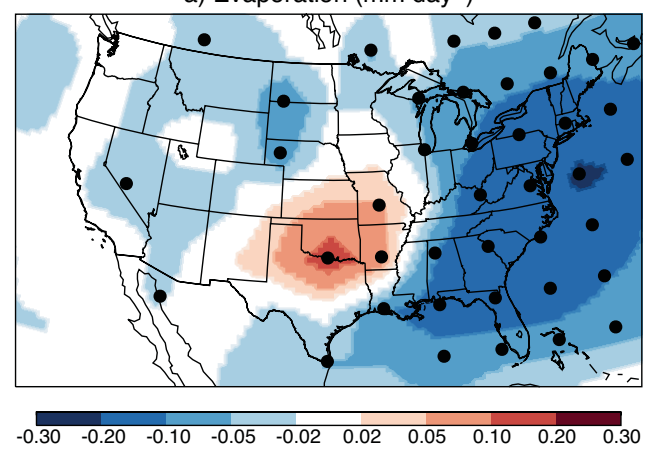

c) Cloud Cover (\%)

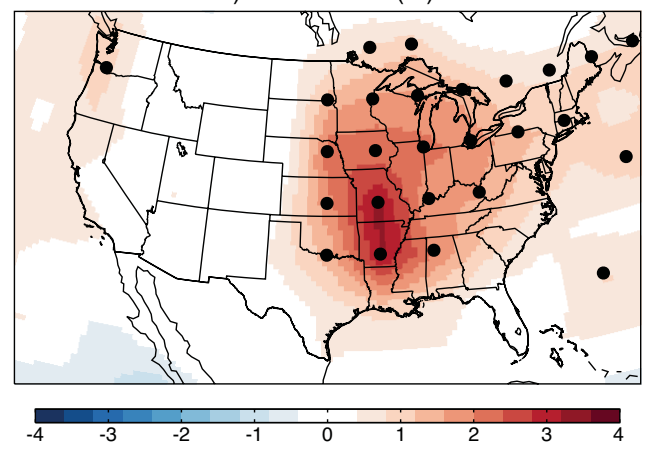

b) Precipitation $\left(\mathrm{mm}\right.$ day $\left.^{-1}\right)$

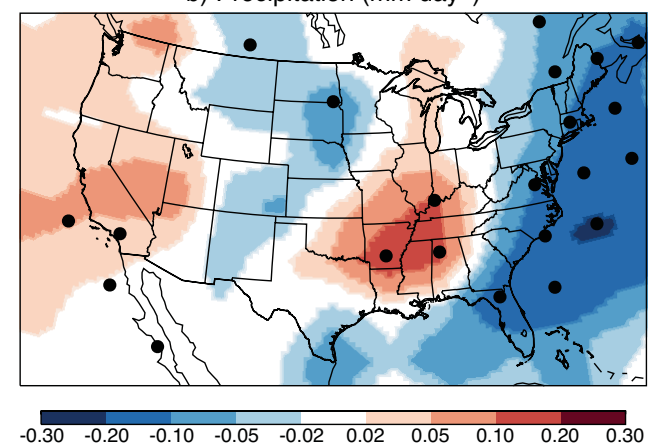

d) Soil Moisture Availability (\%)

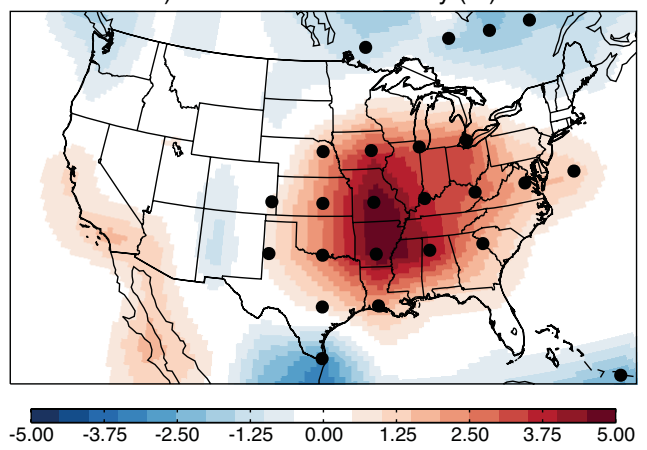

Fig. 6. Effect of US anthropogenic aerosols on annual mean evaporation, precipitation, cloud cover, and soil moisture availability for the 1970-1990 period. Values represent the mean differences between 5-member ensemble GCM simulations including vs. excluding US anthropogenic aerosol sources, and considering both the aerosol direct and indirect effects. Cloud cover change and soil moisture availability are shown as absolute percentages. Changes significant at the 95th percentile are marked with a dot.

\subsection{Hydrology and dynamics}

Aerosols affect the hydrological cycle by reducing evaporation (due to reduced surface solar radiation) and by altering cloud cover and precipitation. Figure 6 shows the annual mean response of evaporation, precipitation, soil moisture availability, and cloud cover to US anthropogenic aerosols for the 1970-1990 period. The changes shown in Fig. 6 are for the total aerosol effect (direct + indirect), but similar responses with less statistical significance are found when only the aerosol direct effect is considered.

Reduced solar radiation at the surface decreases annual mean evaporation rates in the eastern US and the North Atlantic (Fig. 6a). The change is greatest in summer, when evaporation along the eastern seaboard decreases by up to $0.4 \mathrm{~mm} \mathrm{day}^{-1}$. As mentioned in Sect. 3.2, the decrease in latent heat flux associated with lower evaporation rates acts as a buffer to surface temperature changes, reducing the magnitude of aerosol cooling. We find that US anthropogenic aerosols decrease latent heat fluxes much more in summer (6.6 $\mathrm{W} \mathrm{m}^{-2}$ for $1970-1990$ averaged over mid-Atlantic US) than in autumn $\left(0.6 \mathrm{~W} \mathrm{~m}^{-2}\right)$, reflecting the greater availability of soil moisture in summer. In contrast to the general decrease in evaporation rates over the US, we find an increase in the south-central region. This is due to changes in soil moisture as discussed below.
The reduction in evaporation in the eastern US results in a decrease of downwind precipitation along the eastern seaboard (Fig. 6b). The decrease in precipitation is additionally promoted by the aerosol cloud lifetime effect (second aerosol indirect effect), which reduces the precipitation efficiency of clouds. The cloud lifetime effect is applied in the model to liquid stratiform clouds only, and this appears to be the dominant cause for the increase in eastern US cloud cover in Fig. 6c. We find little net change in moist convective cloud cover.

In contrast to the general slowdown of the hydrological cycle over the US, we find that evaporation and precipitation increase in the south central US. This is mostly driven by a summertime aerosol-induced change in circulation. Figure 7 shows the effect of US anthropogenic aerosols on $850 \mathrm{hPa}$ geopotential heights in summer. Aerosols cool the North Atlantic (Fig. 2), strengthening the Bermuda High and thus the onshore flow of marine air from the Gulf of Mexico that is the principal source of moisture for the central and eastern US in summer. This enhances cloud cover, precipitation, and soil moisture over the south-central US (Fig. 6). A similar increase in central US precipitation due to anthropogenic sulfate was presented but not discussed by Jones et al. (2007). Increased cloud cover in the central US due to anthropogenic aerosols explains the particularly strong radiative and surface cooling effects in that region (Figs. 2 and 3). 


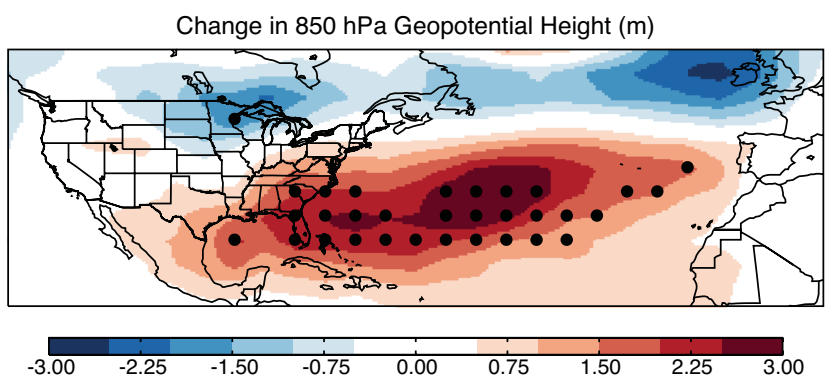

Fig. 7. Change in the summer mean $850 \mathrm{hPa}$ geopotential height due to US anthropogenic aerosols for the 1970-1990 period. Values represent the mean difference between 5-member ensemble GCM simulations including vs. excluding US anthropogenic aerosol sources, and considering both the aerosol direct and indirect effects. Changes significant at the 95th percentile are marked with a dot.

This is consistent with previous observational studies of the US warming hole which found it to be associated with additional moisture from the Gulf of Mexico causing enhanced evapotranspiration (Pan et al., 2004) and cloud cover (Robinson et al., 2002). Our work suggests that US anthropogenic aerosols may be the drivers of changes in circulation causing central US cooling.

\section{Aerosol effects on 1950-2050 trends in US surface air temperature}

Our analysis of the climate effects of US anthropogenic aerosols has focused so far on the 1970-1990 period when the US aerosol loading was the largest. Leibensperger et al. (2012) presented a detailed analysis of US anthropogenic aerosol trends for the 1950-2050 period. US aerosol loading (and corresponding radiative forcing) increased from 1950 to 1980 , decreased since then, and is projected to continue decreasing in the future (Fig. 2). Most of the anthropogenic aerosol radiative forcing is due to sulfate produced by oxidation of $\mathrm{SO}_{2}$. Emissions of $\mathrm{SO}_{2}$ in the US decreased by $56 \%$ from their peak in 1980 to 2008 according to EPA (2010) and this is verified by observed trends in sulfate wet deposition (Leibensperger et al., 2012). US sources of $\mathrm{SO}_{2}$ and other aerosol precursors in the IPCC A1B scenario are projected to continue to decrease until 2020 and then level off.

Figure 8 shows the 1950-2050 simulated cooling trends over the mid-Atlantic US due to US anthropogenic aerosol sources. Cooling increased from $-0.3^{\circ} \mathrm{C}$ in the 1950 s to $-0.65^{\circ} \mathrm{C}$ in the $1970 \mathrm{~s}$, remained flat until 1995 , and then decreased back to $-0.3^{\circ} \mathrm{C}$ by 2010 . Further decrease in aerosol cooling is projected over the coming decades but at a much slower rate, to $-0.2^{\circ} \mathrm{C}$ by 2030 . This trend in cooling is well correlated with the model trend in US aerosol sources (Leibensperger et al., 2012).

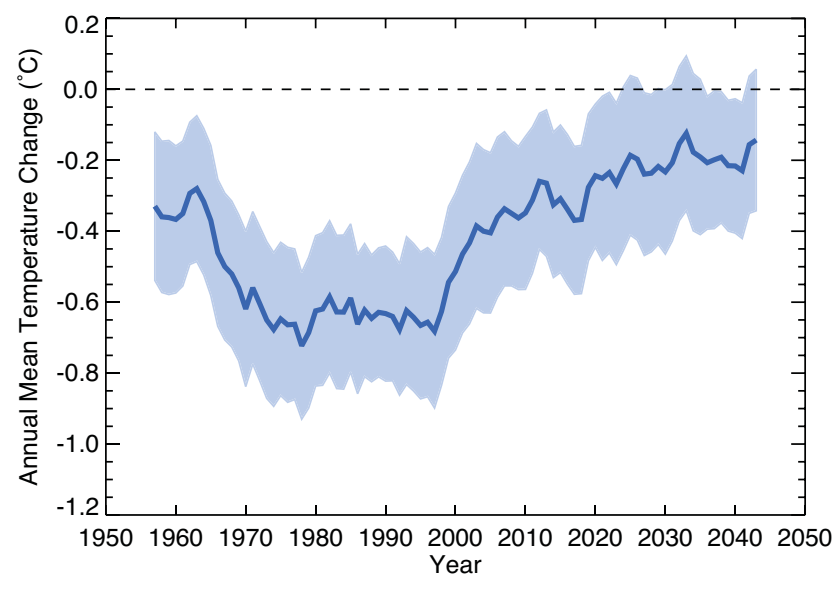

Fig. 8. Change in annual mean surface air temperature over the mid-Atlantic US (boxed region in Fig. 2) due to US anthropogenic aerosol sources. Values are differences for 5-member ensembles between a 1950-2050 control simulation including radiative forcing from both greenhouse gases and aerosols (direct and indirect effects) and a sensitivity simulation with US anthropogenic aerosol sources shut off. The time series has been smoothed with a $15-\mathrm{yr}$ moving average. Shading indicates the $95 \%$ confidence interval.

The trend of aerosol cooling over the mid-Atlantic US in Fig. 8 implies that most of the $0.5^{\circ} \mathrm{C}$ warming over the US expected between 1980 and 2050 from aerosol decreases has in fact already been realized by 2010 . The 1980-2010 warming trend in the model can be compared to the observational record. Figure 9 shows the observed (GISTEMP; http: //data.giss.nasa.gov/gistemp/) 1950-2010 time series of surface air temperature anomalies over the mid-Atlantic US in comparison to the control model simulation and to the sensitivity simulation with no US anthropogenic aerosol sources. Anomalies are relative to the 1951-1980 means in the observations and the control simulation and have been filtered by a 15-yr moving average. Observed and simulated trends for different time periods are summarized in Table 1.

The observations show no significant warming between 1960 and $1979\left(+0.01 \pm 0.20^{\circ} \mathrm{Cdecade}^{-1}\right)$. Our control simulation, which incorporates US anthropogenic aerosols, reproduces this result $\left(-0.02 \pm 0.20^{\circ} \mathrm{C}\right.$ decade $\left.^{-1}\right)$. The simulation without US anthropogenic aerosols, however, produces a warming trend over this period $\left(+0.30 \pm 0.19^{\circ} \mathrm{C} \mathrm{decade}^{-1}\right)$. We conclude that the increasing abundance of US anthropogenic aerosols effectively offset greenhouse warming before 1980 (difference in trends significant at the 90th percentile). Figure 9 shows significant observed warming over the eastern US for the 1980-2009 period $\left(+0.21 \pm 0.20^{\circ} \mathrm{C}\right.$ decade $\left.^{-1}\right)$. Anthropogenic aerosol sources in the US peaked in 1980 and decreased afterward. Our control simulation reproduces the post-1980 warming with a rate of $+0.41 \pm 0.08^{\circ} \mathrm{C} \mathrm{decade}^{-1}$ for the 1980-2009 period. The sensitivity simulation without US anthropogenic 
Table 1. Trends in surface air temperature $\left({ }^{\circ} \mathrm{C}\right.$ decade $\left.{ }^{-1}\right)$ in the mid-Atlantic US ${ }^{\mathrm{a}}$.

\begin{tabular}{llll}
\hline & $1960-1979$ & $1980-2010$ & $2020-2050$ \\
\hline Observations $^{\mathrm{b}}$ & $+0.01 \pm 0.20^{\mathrm{c}}$ & $+0.21 \pm 0.18$ & - \\
Model $_{\text {Control }^{\mathrm{d}}}$ & & & \\
No US Anthropogenic $^{\mathrm{A}}$ & $+0.02 \pm 0.20$ & $+0.41 \pm 0.08$ & $+0.29 \pm 0.07$ \\
Aerosols $^{\mathrm{e}}$ & & & \\
\hline
\end{tabular}

${ }^{\text {a }}$ Averages for the boxed region in Fig. 2.

b Observations from the NASA GISS Surface Temperature Analysis (GISTEMP; http://data.giss.nasa.gov/gistemp/).

c $95 \%$ confidence interval.

${ }^{\mathrm{d}}$ Control simulation including best estimates of greenhouse gas, aerosol, and natural radiative forcing.

${ }^{\mathrm{e}}$ Sensitivity simulation excluding US anthropogenic sources of $\mathrm{SO}_{2}, \mathrm{NO}_{\mathrm{x}}$, black carbon (BC), and primary organic aerosol (POA).

aerosols shows slower warming $\left(+0.30 \pm 0.10^{\circ} \mathrm{Cdecade}^{-1}\right.$, difference from control simulation significant at the 90th percentile), which represents a continuation of the 19601979 trend due to greenhouse warming. The larger trend in the control simulation reflects the acceleration of positive radiative forcing due to loss of the aerosol radiation shield. Beyond 2010 the rate of warming in the control simulation eases and eventually approaches that of the sensitivity simulation with no US anthropogenic aerosol sources.

\section{Conclusions}

Aerosol concentrations over the US peaked in the 19701990 period, have decreased rapidly since, and are projected to continue decreasing in the future as a result of air quality regulations to protect public health. We used a general circulation model (GISS GCM 3) to study the regional climate response to this time-dependent regional aerosol radiative forcing. The climate response to US anthropogenic aerosol sources was diagnosed through 1950-2050 control climate simulations including our best estimates of timedependent greenhouse gas concentrations and aerosol distributions (Leibensperger et al., 2012) and through sensitivity simulations with US anthropogenic aerosol sources shut off. Our goal was to determine how aerosol trends have contributed to recent climate trends over the US and to examine the climate consequences of further US aerosol reductions in the future.

We find that peak US anthropogenic aerosol loadings (1970-1990) cooled the central and eastern US by 0.5$1.0^{\circ} \mathrm{C}$ on an annual mean basis. This cooling is strongest in summer and autumn, and especially strong during heat waves. Surface solar radiation was reduced by up to $8 \mathrm{~W} \mathrm{~m}^{-2}$ $\left(5 \mathrm{~W} \mathrm{~m}^{-2}\right.$ from the direct effect alone) during the same pe-

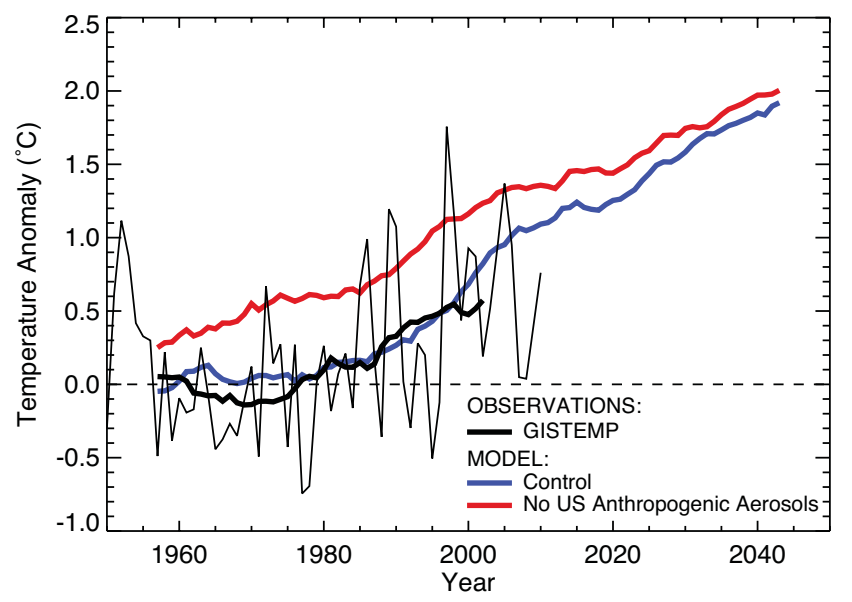

Fig. 9. 1950-2050 trends in annual mean surface air temperatures over the mid-Atlantic US (boxed region in Fig. 2). Observations (GISTEMP) are compared to the control simulation including greenhouse and aerosol forcings and to the sensitivity simulation with no US anthropogenic aerosols. Observations are the anomaly relative to the observed 1951-1980 mean and are shown for individual years (thin line) and for a $15-y r$ moving average (thick line). Model temperatures are the 5-member ensemble mean anomaly relative to the 1951-1980 mean of the control simulation, and are shown as 15 -yr moving averages.

riod of peak aerosol loading. The reduction of solar radiation and prolonged cloud lifetimes slowed the hydrological cycle in the eastern US by reducing evaporation and precipitation ( $0.2 \mathrm{~mm} \mathrm{day}^{-1}$ annual mean, $0.4 \mathrm{~mm} \mathrm{day}^{-1}$ in summer).

We find the cooling effect of US anthropogenic aerosols to be largest in the central US. This spatial pattern is found in observations (Fig. 1) and has been reported previously as a "warming hole" (Pan et al., 2004; Kunkel et al., 2006). This is due in the model to aerosol-driven cooling of the western North Atlantic that enhances the southerly flow of moist air from the Gulf of Mexico. This hydrological contribution to the central US "warming hole" has been previously identified from observations by Robinson et al. (2002) and Pan et al. (2004), and attributed to sea surface temperature (SST) anomalies. We show that this mechanism is consistent with the expected effect of US anthropogenic aerosols on North Atlantic SSTs.

Our model results show that US anthropogenic aerosols can explain the observed lack of warming over the eastern US from 1930 to 1980 followed by very rapid post-1980 warming. Without US anthropogenic aerosol sources, we find in the model a relatively constant rate of warming over the 1950-2050 period, driven by increasing greenhouse gases. Increasing aerosols until 1980 offset the warming. Decreasing aerosol after 1980 accelerated the warming due to the loss of the aerosol cooling shield. We find that the observed warming from 1990 to 2010 is significantly greater than would have been expected from greenhouse gases alone. 
We project that future reductions in US aerosol sources will increase warming over the eastern US by $0.1^{\circ} \mathrm{C}$. However, we find that most of the warming due to reducing US aerosol sources for air quality objectives has in fact already been realized $\left(0.35^{\circ} \mathrm{C}\right.$ over the eastern US in $\left.1980-2010\right)$.

Our results have several implications for US air quality policy. We find that reductions in aerosol sources to improve air quality have elicited a strong regional warming response over the past $20 \mathrm{yr}$. We also find that future aerosol reductions should have relatively little additional climate impact because aerosol sources are already low by now. It has been suggested that future black carbon (BC) emission controls could provide relief from future warming (Bond, 2007; Grieshop et al., 2009; Penner et al., 2010), but we find that $\mathrm{BC}$ sources in the US are too small for their climatic impact to be significant.

Relating aerosol radiative forcing to regional climate change is challenging. There are many model uncertainties involved in the mechanisms of aerosol-cloud interactions, the response of the hydrological cycle, the lateral transport of heat in the ocean (the Q-flux parameterization used here does not allow for change in that transport), and other aspects of the climate model. Multi-model analyses are needed to address the robustness of results (National Research Council, 2005). Our ability to reproduce observed 1950-2010 temperature trends lends some confidence to our conclusions.

Although our results are specific to the US, they also warn of possibly strong regional warming over East Asia in the coming decades as China embarks on vigorous emission controls to address its pressing aerosol pollution problem. The climate response to anthropogenic aerosols in East Asia may be very different from the US because of the greater contribution of $\mathrm{BC}$ to the aerosol mix and because of specific meteorological features such as the monsoon. Application of our approach to that region would be of considerable interest.

Acknowledgements. This work was funded by the Electric Power Research Institute (EPRI) and by an EPA Science to Achieve Results (STAR) Graduate Research Fellowship to Eric Leibensperger. The EPRI and EPA have not officially endorsed this publication and the views expressed herein may not reflect those of the EPRI and EPA. This work utilized resources and technical support offered by the Harvard University School of Engineering and Applied Science (SEAS) Instructional and Research Computing Services (IRCS). We would like to thank Jeff Jonas and Mark Chandler of NASA GISS for help with ocean heat flux calculations and Jack Yatteau for computational assistance. We also thank three anonymous referees.

Edited by: E. Highwood

\section{References}

Adams, P. J. and Seinfeld, J. H.: Predicting global aerosol size distributions in general circulation models, J. Geophys. Res.Atmos., 107, 4370, doi:10.1029/2001JD001010, 2002.

Andreae, M., Jones, C., and Cox, P.: Strong present-day aerosol cooling implies a hot future, Nature, 435, 1187-1190, doi:10.1038/nature03671, 2005.

Bauer, S. E., Menon, S., Koch, D., Bond, T. C., and Tsigaridis, K.: A global modeling study on carbonaceous aerosol microphysical characteristics and radiative effects, Atmos. Chem. Phys., 10, 7439-7456, doi:10.5194/acp-10-7439-2010, 2010.

Bey, I., Jacob, D., Yantosca, R., Logan, J., Field, B., Fiore, A., Li, Q., Liu, H., Mickley, L., and Schultz, M.: Global modeling of tropospheric chemistry with assimilated meteorology: Model description and evaluation, J. Geophys. Res.-Atmos., 106, 2307323095, 2001.

Bond, T. C.: Can warming particles enter global climate discussions?, Environ. Res. Lett., 2, 045030, doi:10.1088/17489326/2/4/045030, 2007.

Bond, T. C., Bhardwaj, E., Dong, R., Jogani, R., Jung, S., Roden, C., Streets, D. G., and Trautmann, N. M.: Historical emissions of black and organic carbon aerosol from energy-related combustion, 1850-2000, Global Biogeochem. Cy., 21, GB2018, doi:10.1029/2006GB002840, 2007.

Bouwman, A., Lee, D., Asman, W., Dentener, F., Van Der Hoek, K., and Olivier, J.: A global high-resolution emission inventory for ammonia, Global Biogeochem. Cy., 11, 561-587, 1997.

Brasseur, G. and Roeckner, E.: Impact of improved air quality on the future evolution of climate, Geophys. Res. Lett., 32, L23704, doi:10.1029/2005GL023902, 2005.

Chang, W., Liao, H., and Wang, H.: Climate responses to direct radiative forcing of anthropogenic aerosols, tropospheric ozone, and long-lived greenhouse gases in eastern China over 19512000, Adv. Atmos. Sci., 26, 748-762, doi:10.1007/s00376-0099032-4, 2009.

Chen, W.-T., Lee, Y. H., Adams, P. J., Nenes, A., and Seinfeld, J. H.: Will black carbok mitigation dampen aerosol indirect forcing?, Geophys. Res. Lett., 37, L09801, doi:10.1029/2010GL042886, 2010a.

Chen, W.-T., Nenes, A., Liao, H., Adams, P. J., Li, J.-L. F., and Seinfeld, J. H.: Global climate response to anthropogenic aerosol indirect effects: Present day and year 2100, J. Geophys. Res.Atmos., 115, D12207, doi:10.1029/2008JD011619, 2010 b.

Chin, M., Rood, R., Lin, S., Muller, J., and Thompson, A.: Atmospheric sulfur cycle simulated in the global model GOCART: Model description and global properties, J. Geophys. Res.-Atmos., 105, 24671-24687, 2000.

Chung, S. and Seinfeld, J.: Global distribution and climate forcing of carbonaceous aerosols, J. Geophys. Res.-Atmos., 107, 4407, doi:10.1029/2001JD001397, 2002.

Del Genio, A., Yao, M., Kovari, W., and Lo, K.: A prognostic cloud water parameterization for global climate models, J. Climate, 9, 270-304, 1996.

Duncan, B., Martin, R., Staudt, A., Yevich, R., and Logan, J.: Interannual and seasonal variability of biomass burning emissions constrained by satellite observations, J. Geophys. Res.-Atmos., 108, 4100, doi:10.1029/2002JD002378, 2003.

Fiore, A. M., Jacob, D. J., Field, B. D., Streets, D. G., Fernandes, S. D., and Jang, C.: Linking ozone pollution and climate change: 
The case for controlling methane, Geophys. Res. Lett., 29, 1919, doi:10.1029/2002GL015601, 2002.

Fischer-Bruns, I., Banse, D. F., and Feichter, J.: Future impact of anthropogenic sulfate aerosol on North Atlantic climate, Clim. Dynam., 32, 511-524, doi:10.1007/s00382-008-0458-7, 2009.

Fischer-Bruns, I., Feichter, J., Kloster, S., and Schneidereit, A.: How present aerosol pollution from North America impacts North Atlantic climate, Tellus A, 574-589, doi:10.1111/j.16000870.2010.00446.x, 2010.

Fountoukis, C. and Nenes, A.: Continued development of a cloud droplet formation parameterization for global climate models, J. Geophys. Res.-Atmos., 110, D11212, doi:10.1029/2004JD005591, 2005.

Grieshop, A. P., Reynolds, C. C. O., Kandlikar, M., and Dowlatabadi, H.: A black-carbon mitigation wedge, Nat. Geosci., 2, 533-534, 2009.

Hansen, J., Fung, I., Lacis, A., Rind, D., Lebedeff, S., Ruedy, R., Russell, G., and Stone, P.: Global climate changes as forecast by Goddard Institute For Space Studies 3-dimensional model, J. Geophys. Res.-Atmos., 93, 9341-9364, 1988.

Hansen, J., Ruedy, R., Sato, M., Imhoff, M., Lawrence, W., Easterling, D., Peterson, T., and Karl, T.: A closer look at United States and global surface temperature change, J. Geophys. Res.-Atmos., 106, 23947-23963, doi:10.1029/2001JD000354, 2001.

Hansen, J., Sato, M., Nazarenko, L., Ruedy, R., Lacis, A., Koch, D., Tegen, I., Hall, T., Shindell, D., Santer, B., Stone, P., Novakov, T., Thomason, L., Wang, R., Wang, Y., Jacob, D., Hollandsworth, S., Bishop, L., Logan, J., Thompson, A., Stolarski, R., Lean, J., Willson, R., Levitus, S., Antonov, J., Rayner, N., Parker, D., and Christy, J.: Climate forcings in Goddard Institute for Space Studies SI2000 simulations, J. Geophys. Res.-Atmos., 107, 4347-4383, doi:10.1029/2001JD001143, 2002.

Hansen, J., Sato, M., Ruedy, R., Nazarenko, L., Lacis, A., Schmidt, G. A., Russell, G., Aleinov, I., Bauer, M., Bauer, S., Bell, N., Cairns, B., Canuto, V., Chandler, M., Cheng, Y., Del Genio, A. D., Faluvegi, G., Fleming, E., Friend, A., Hall, T., Jackman, C., Kelley, M., Kiang, N., Koch, D., Lean, J., Lerner, J., Lo, K., Menon, S., Miller, R., Minnis, P., Novakov, T., Oinas, V., Perlwitz, Ja., Perlwitz, Ju., Rind, D., Romanou, A., Shindell, D., Stone, P., Sun, S., Tausnev, N., Thresher, D., Wielicki, B. Wong, T., Yao, M., and Zhang, S.: Efficacy of climate forcings, J. Geophys. Res.-Atmos., 110, D18104, doi:10.1029/2005JD005776, 2005.

Hegerl, G. C., Zwiers, F. W., Braconnot, P., Gillett, N. P., Luo, Y., Marengo Orsini, J. A., Nicholls, N., Penner, J. E., and Stott, P. A.: Understanding and Attributing Climate Change, in: Climate Change 2007: The Physical Science Basis, New York, NY, 2007.

Hoose, C., Lohmann, U., Bennartz, R., Croft, B., and Lesins, G.: Global simulations of aerosol processing in clouds, Atmos. Chem. Phys., 8, 6939-6963, doi:10.5194/acp-8-6939-2008, 2008.

Jacob, D. J. and Winner, D. A.: Effect of climate change on air quality, Atmos. Environ., 43, 51-63, 2009.

Jacobson, M. Z.: Short-term effects of agriculture on air pollution and climate in California, J. Geophys. Res.-Atmos., 113, D23101, doi:10.1029/2008JD010689, 2008.

Jacobsosn, M. Z.: Short-term effects of controlling fossil-fuel soot, biofuel soot and gases, and methane on climate, Arctic ice, and air pollution health, J. Geophys. Res.-Atmos., 115, D14209,
doi:10.1029/2009JD013795, 2010.

Jones, A., Roberts, D. L., Woodage, M. J., and Johnson, C. E.: Indirect sulphate aerosol forcing in a climate model with an interactive sulphy cycle, J. Geophys. Res., 106, 20293-20310, 2001.

Jones, A., Haywood, J. M., and Boucher, O.: Aerosol forcing, climate response and climate sensitivity in the Hadley Centre climate model, J. Geophys. Res.-Atmos., 112, D20211, doi:10.1029/2007JD008688, 2007.

Khairoutdinov, M. and Kogan, Y.: A new cloud physics parameterization in a large-eddy simulation model of marine stratocumulus, Mon. Weather Rev., 128, 229-243, 2000.

Kloster, S., Dentener, F., Feichter, J., Raes, F., Lohmann, U., Roeckner, E., and Fischer-Bruns, I.: A GCM study of future climate response to aerosol pollution reductions, Clim. Dynam., 34, 11771194, doi:10.1007/s00382-009-0573-0, 2009.

Koch, D. and Del Genio, A. D.: Black carbon semi-direct effects on cloud cover: review and synthesis, Atmos. Chem. Phys., 10, 7685-7696, doi:10.5194/acp-10-7685-2010, 2010.

Koch, D., Jacob, D. J., Tegen, I., Rind, D., and Chin, M.: Tropospheric sulfur simulation and sulfate direct radiative forcing in the GISS GCM, J. Geophys. Res., 104, 23799-23822, 1999.

Koch, D., Bauer, S. E., Del Genio, A. D., Faluvegi, G., McConnell, J. R., Menon, S., Miller, R. L., Rind, D., Ruedy, R., Schmidt, G. A., and Shindell, D.: Coupled aerosol-chemistryclimate twentieth-century transient model investigation: Trends in short-lived species and climate response, J. Climate, 24, 26932714, doi:10.1175/2011JCLI3582.1, 2011.

Kunkel, K., Liang, X.-Z., Zhu, J., and Lin, Y.: Can CGCMs simulate the twentieth-century "warming hole" in the central United States?, J. Climate, 19, 4137-4153, 2006.

Lee, W. and Kim, M.: Effects of radiative forcing by black carbon aerosol on spring rainfall decrease over Southeast Asia, Atmos. Environ., 44, 3739-3744, 2010.

Leibensperger, E. M., Mickley, L. J., and Jacob, D. J.: Sensitivity of US air quality to mid-latitude cyclone frequency and implications of 1980-2006 climate change, Atmos. Chem. Phys., 8, 7075-7086, doi:10.5194/acp-8-7075-2008, 2008.

Leibensperger, E. M., Mickley, L. J., Jacob, D. J., Chen, W.-T., Seinfeld, J. H., Nenes, A., Adams, P. J., Streets, D. G., Kumar, N., and Rind, D.: Climatic effects of 1950-2050 changes in US anthropogenic aerosols - Part 1: Aerosol trends and radiative forcing, Atmos. Chem. Phys., 12, 3333-3348, doi:10.5194/acp12-3333-2012, 2012.

Levy, H., Schwarzkopf, M. D., Horowitz, L., Ramaswamy, V., and Findell, K. L.: Strong sensitivity of late 21 st century climate to projected changes in short-lived air pollutants, J. Geophys. Res.Atmos., 113, D06102, doi:10.1029/2007JD009176, 2008.

Liao, H., Seinfeld, J., Adams, P., and Mickley, L.: Global radiative forcing of coupled tropospheric ozone and aerosols in a unified general circulation model, J. Geophys. Res.-Atmos., 109, D16207, doi:10.1029/2003JD004456, 2004.

Liao, H., Henze, D. K., Seinfeld, J. H., Wu, S., and Mickley, L. J.: Biogenic secondary organic aerosol over the United States: Comparison of climatological simulations with observations, J. Geophys. Res.-Atmos., 112, D06201, doi:10.1029/2006JD007813, 2007.

Liepert, B. and Tegen, I.: Multidecadal solar radiation trends in the United States and Germany and direct tropospheric aerosol forcing, J. Geophys. Res.-Atmos., 107, 4153, 
doi:10.1029/2001JD000760, 2002.

Liu, B., Xu, M., Henderson, M., and Gong, W.: A spatial analysis of pan evaporation trends in China, 1955-2000, J. Geophys. Res.Atmos., 109, D15102, doi:10.1029/2004JD004511, 2004a.

Liu, B., Xu, M., Henderson, M., Qi, Y., and Li, Y.: Taking China's temperature: Daily range, warming trends, and regional variations, 1955-2000, J Climate, 17, 4453-4462, 2004b.

Long, C. N., Dutton, E. G., Augustine, J. A., Wiscombe, W., Wild, M., Mcfarlane, S. A., and Flynn, C. J.: Significant decadal brightening of downwelling shortwave in the continental United States, J. Geophys. Res.-Atmos., 114, D00D06, doi:10.1029/2008JD011263, 2009.

Makowski, K., Jaeger, E. B., Chiacchio, M., Wild, M., Ewen, T., and Ohmura, A.: On the relationship between diurnal temperature range and surface solar radiation in Europe, J. Geophys. Res.-Atmos., 114, D00D07, doi:10.1029/2008JD011104, 2009.

Martin, G. M., Johnson, D. W., and Spice, A.: The measurement and parameterization of effective radius of droplets in warm stratocumulus clouds, J. Atmos. Sci., 51, 1823-1842, 1994.

Menon, S., Hansen, J., Nazarenko, L., and Luo, Y.: Climate effects of black carbon aerosols in China and India, Science, 297, 22502253, 2002.

Mickley, L. J., Leibensperger, E. M., Jacob, D. J., and Rind, D.: Regional warming from aerosol removal over the United States: Results from a transient 2010-2050 climate simulation, Atmos. Environ., 46, 545-553, doi:10.1016/j.atmosenv.2011.07.030, 2012.

Mitchell, J., Davis, R., Ingram, W., and Senior, C.: On surface temperature, greenhouse gases, and aerosols: Models and observations, J. Climate, 8, 2364-2386, 1995.

Morales, R. and Nenes, A.: Characteristic updrafts for computing distribution-averaged cloud droplet number, autoconversion rate and effective radius, J. Geophys. Res., 115, D18220, doi:10.1029/2009JD013233, 2010.

Moss, R. H., Edmonds, J. A., Hibbard, K. A., Manning, M. R., Rose, S. K., van Vuuren, D. P., Carter, T. R., Emori, S., Kainuma, M., Kram, T., Meehl, G. A., Mitchell, J. F. B., Nakicenovic, N., Riahi, K., Smith, S. J., Stouffer, R. J., Thomson, A. M., Weyant, J. P., and Wilbanks, T. J.: The next generation of scenarios for climate change research and assessment, Nature, 463, 747-756, doi:10.1038/nature08823, 2010.

Nakićenović, N. and Swart, R.: Special Report on Emission Scenarios. A Special Report of the Working Group III of Intergovernmental Panel on Climate Change, in: A Special Report of the Working Group III of Intergovernmental Panel on Climate Change, Cambridge University Press, Cambridge, UK and New York, NY USA, 569, 2000.

National Research Council: Radiative forcing of climate change: Expanding the concept and addressing uncertainties, National Academies Press, Washington, DC, 2005.

Nenes, A. and Seinfeld, J.: Parameterization of cloud droplet formation in global climate models, J. Geophys. Res.-Atmos., 108, 4415, doi:10.1029/2002JD002911, 2003.

Olivier, J. G. J. and Berdowski, J. J. M.: Global emissions sources and sinks, in: The Climate System, edited by: Berdowski, J., Guicherit, R., and Heij, B. J., A. A. Balkema Publishers/Swets and Zeitliner Publishers, Lisse, The Netherlands, 33-78, 2001.

Pan, Z. T., Arritt, R. W., Takle, E. S., Gutowski, W. J., Anderson, C. J., and Segal, M.: Altered hydrologic feedback in a warming climate introduces a "warming hole", Geophys. Res. Lett., 31,
L17109, doi:10.1029/2004GL020528, 2004.

Park, R., Jacob, D., Field, B., Yantosca, R., and Chin, M.: Natural and transboundary pollution influences on sulfatenitrate-ammonium aerosols in the United States: Implications for policy, J. Geophys. Res.-Atmos., 109, D15204, doi:10.1029/2003JD004473, 2004.

Park, R., Jacob, D., Kumar, N., and Yantosca, R.: Regional visibility statistics in the United States: Natural and transboundary pollution influences, and implications for the Regional Haze Rule, Atmos. Environ., 40, 5405-5423, doi:10.1016/j.atmosenv.2006.04.059, 2006.

Penner, J. E., Prather, M. J., Isaksen, I. S. A., Fugelstvedt, J. S., Klimont, Z., and Stevenson, D. S.: Short-lived uncertainty?, Nat. Geosci., 3, 587-588, 2010.

Peterson, T., Golubev, V. S., and Groisman, P. Y.: Evaporation Losing its Strength, Nature, 377, 687-688, 1995.

Philipona, R., Behrens, K., and Ruckstuhl, C.: How declining aerosols and rising greenhouse gases forced rapid warming in Europe since the 1980s, Geophys. Res. Lett., 36, L02806, doi:10.1029/2008GL036350, 2009.

Pierce, J. and Adams, P.: Global evaluation of CCN formation by direct emission of sea salt and growth of ultrafine sea salt, J. Geophys. Res.-Atmos., 111, D06203, doi:10.1029/2005JD006186, 2006.

Pye, H. O. T., Liao, H., Wu, S., Mickley, L. J., Jacob, D. J., Henze, D. K., and Seinfeld, J. H.: Effect of changes in climate and emissions on future sulfate-nitrate-ammonium aerosol levels in the United States, J. Geophys. Res.-Atmos., 114, D01205, doi:10.1029/2008JD010701, 2009.

Qian, Y. and Giorgi, F.: Regional climatic effects of anthropogenic aerosols? The case of Southwestern China, Geophys. Res. Lett., 27, 3521-3524, 2000.

Raes, F. and Seinfeld, J. H.: New Directions: Climate change and air pollution abatement: A bumpy road, Atmos. Environ., 43, 5132-5133, doi:10.1016/j.atmosenv.2009.06.001, 2009.

Rayner, N., Parker, D., Horton, E., Folland, C., Alexander, L., Rowell, D., Kent, E., and Kaplan, A.: Global analyses of sea surface temperature, sea ice, and night marine air temperature since the late nineteenth century, J. Geophys. Res.-Atmos., 108, 4407, doi:10.1029/2002JD002670, 2003.

Rind, D., Lerner, J., Jonas, J., and Mclinden, C.: Effects of resolution and model physics on tracer transports in the NASA Goddard Institute for Space Studies general circulation models, J. Geophys. Res.-Atmos., 112, D09315, doi:10.1029/2006JD007476, 2007.

Rind, D., Lean, J., Lerner, J., Lonergan, P., and Leboissitier, A.: Exploring the stratospheric/tropospheric response to solar forcing, J. Geophys. Res.-Atmos., 113, D24103, doi:10.1029/2008JD010114, 2008.

Rind, D., Jonas, J., Stammerjohn, S., and Lonergan, P.: The Antarctic ozone hole and the Northern Annular Mode: A stratospheric interhemispheric connection, Geophys. Res. Lett., 36, L09818, doi:10.1029/2009GL037866, 2009a.

Rind, D., Lerner, J., Mclinden, C., and Perlwitz, J.: Stratospheric ozone during the Last Glacial Maximum, Geophys. Res. Lett. 36, L09712, doi:10.1029/2009GL037617, 2009b.

Robinson, W. A., Reudy, R., and Hansen, J. E.: General circulation model simulations of recent cooling in the east-central United States, J. Geophys. Res.-Atmos., 107, 4748-4761, 
doi:10.1029/2001JD001577, 2002.

Robock, A., Mu, M., Vinnikov, K., Trofimova, I., and Adamenko, T.: Forty-five years of observed soil moisture in the Ukraine: No summer desiccation (yet), Geophys. Res. Lett., 32, L03401, doi:10.1029/2004GL021914, 2005.

Roderick, M. L., Rotstayn, L. D., Farquhar, G. D., and Hobbins, M. T.: On the attribution of changing pan evaporation, Geophys. Res. Lett., 34, L17403, doi:10.1029/2007GL031166, 2007.

Ruckstuhl, C., Philipona, R., Behrens, K., Collaud Coen, M., Dürr, B., Heimo, A., Mätzler, C., Nyeki, S., Ohmura, A., Vuilleumier, L., Weller, M., Wehrli, C., and Zelenka, A.: Aerosol and cloud effects on solar brightening and the recent rapid warming, Geophys. Res. Lett., 35, L12708, doi:10.1029/2008GL034228, 2008.

Schmidt, G., Ruedy, R., Hansen, J., Aleinov, I., Bell, N., Bauer, M., Bauer, S., Cairns, B., Canuto, V., Cheng, Y., Del Genio, A., Faluvegi, G., Friend, A., Hall, T., Hu, Y., Kelley, M., Kiang, N., Koch, D., Lacis, A., Lerner, J., Lo, K., Miller, R., Nazarenko, L., Oinas, V., Perlwitz, J., Perlwitz, J., Rind, D., Romanou, A., Russell, G., Sato, M., Shindell, D., Stone, P., Sun, S., Tausnev, N., Thresher, D., and Yao, M.: Present-day atmospheric simulations using GISS ModelE: Comparison to in situ, satellite, and reanalysis data, J. Climate, 19, 153-192, 2006.

Schulz, M., Textor, C., Kinne, S., Balkanski, Y., Bauer, S., Berntsen, T., Berglen, T., Boucher, O., Dentener, F., Guibert, S., Isaksen, I. S. A., Iversen, T., Koch, D., Kirkevåg, A., Liu, X., Montanaro, V., Myhre, G., Penner, J. E., Pitari, G., Reddy, S., Seland, Ø., Stier, P., and Takemura, T.: Radiative forcing by aerosols as derived from the AeroCom present-day and pre-industrial simulations, Atmos. Chem. Phys., 6, 5225-5246, doi:10.5194/acp-6-5225-2006, 2006.

Shindell, D. T., Faluvegi, G., Bauer, S. E., Koch, D. M., Unger, N., Menon, S., Miller, R. L., Schmidt, G. A., and Streets, D. G.: Climate response to projected changes in shortlived species under an A1B scenario from 2000-2050 in the GISS climate model, J. Geophys. Res.-Atmos., 112, D20103, doi:10.1029/2007JD008753, 2007.

Shindell, D. T., Levy, H., Schwarzkopf, M. D., Horowitz, L. W., Lamarque, J.-F., and Faluvegi, G.: Multimodel projections of climate change from short-lived emissions due to human activities, J. Geophys. Res.-Atmos., 113, D11109, doi:10.1029/2007JD009152, 2008.

Shindell, D. T., Schulz, M., Ming, Y., Takemura, T., Faluvegi, G., and Ramaswamy, V.: Spatial scales of climate response to inhomogenous radiative forcing, J. Geophys. Res.-Atmos., 115, D19110, doi:10.1029/2010JD014108, 2010.

Streets, D., Bond, T., Carmichael, G., Fernandes, S., Fu, Q., He, D., Klimont, Z., Nelson, S., Tsai, N., Wang, M., Woo, J., and Yarber, K.: An inventory of gaseous and primary aerosol emissions in Asia in the year 2000, J. Geophys. Res.-Atmos., 108, 8809, doi:10.1029/2002JD003093, 2003.

Streets, D., Bond, T., Lee, T., and Jang, C.: On the future of carbonaceous aerosol emissions, J. Geophys. Res.-Atmos., 109, D24212, doi:10.1029/2004JD004902, 2004.

Streets, D. G., Yan, F., Chin, M., Diehl, T., Mahowald, N., Schultz, M., Wild, M., Wu, Y., and Yu, C.: Anthropogenic and natural contributions to regional trends in aerosol optical depth, 1980-2006, J. Geophys. Res.-Atmos., 114, D00D18, doi:10.1029/2008JD011624, 2009.
Sun, S. and Hansen, J. E.: Climate simulations for 1951-2050 with a coupled atmosphere-ocean model, J. Climate, 16, 2807-2826, 2003.

Tai, A. P. K., Mickley, L. J., Jacob, D. J., Leibensperger, E. M., Zhang, L., Fisher, J. A., and Pye, H. O. T.: Meteorological modes of variability for fine particulate matter $\left(\mathrm{PM}_{2.5}\right)$ air quality in the United States: implications for $\mathrm{PM}_{2.5}$ sensitivity to climate change, Atmos. Chem. Phys. Discuss., 11, 31031-31066, doi:10.5194/acpd-11-31031-2011, 2011.

Trenberth, K. E., Jones, P. D., Ambenje, P., Bojariu, R., Easterling, D., Klein Tank, A., Parker, D., Rahimzadeh, F., Renwick, J. A., Rusticucci, M., Soden, B., and Zhai, P.: Observations: Surface and Atmospheric Climate Change, in: Climate Change 2007: The Physical Science Basis, New York, NY, 2007.

US Environmental Protection Agency: Our Nation's Air - Status and Trends through 2008, Washington, DC, 2010.

van Aardenne, J., Dentener, F., and Olivier, J.: A $1^{\circ} \times 1^{\circ}$ resolution data set of historical anthropogenic trace gas emissions for the period 1890-1990, Global Biogeochem. Cy., 15, 909-928, 2001.

Wang, C., Kim, D., Ekman, A. M. L., Barth, M. C., and Rasch, P. J.: Impact of anthropogenic aerosols on Indian summer monsoon, Geophys. Res. Lett., 36, L21704, doi:10.1029/2009GL040114, 2009a.

Wang, H., Schubert, S., Suarez, M., Chen, J., Hoerling, M., Kumar, A., and Pegion, P.: Attribution of the seasonality and regionality in climate trends over the United States during 1950-2000, J. Climate, 22, 2571-2590, 2009b.

Wang, Y., Jacob, D., and Logan, J.: Global simulation of tropospheric $\mathrm{O}_{3}-\mathrm{NO}_{\mathrm{X}}$-hydrocarbon chemistry 1 . Model formulation, J. Geophys. Res.-Atmos., 103, 10713-10725, 1998.

Wild, M.: How well do IPCC-AR4/CMIP3 climate models simulate global dimming/brightening and twentieth-century daytime and nighttime warming?, J. Geophys. Res.-Atmos., 114, D00D11, doi:10.1029/2008JD011372, 2009a.

Wild, M.: Global dimming and brightening: A review, J. Geophys. Res.-Atmos., 114, D00D16, doi:10.1029/2008JD011470, 2009b.

Wild, M., Ohmura, A., and Makowski, K.: Impact of global dimming and brightening on global warming, Geophys. Res. Lett., 34, L04702, doi:10.1029/2006GL028031, 2007.

Wilcox, E. M., Sud, Y. C., and Walker, G.: Sensitivity of borealsummer circulation and precipitation to atmospheric aerosols in selected regions - Part 2: The Americas, Ann. Geophys., 27, 4009-4021, doi:10.5194/angeo-27-4009-2009, 2009.

Wu, S., Mickley, L. J., Leibensperger, E. M., Jacob, D. J., Rind, D., and Streets, D. G.: Effects of 2000-2050 global change on ozone air quality in the United States, J. Geophys. Res.-Atmos., 113, D06302, doi:10.1029/2007JD008917, 2008.

Zhang, Y., Sun, S., Olsen, S. C., Dubey, M. K., and He, J.: CCSM3 simulated regional effects of anthropogenic aerosols for two contrasting scenarios: rising Asian emissions and global reduction of aerosols, Int. J. Climatol., 31, 95-114, doi:10.1002/joc.2060, 2009.

Zwiers, F. and von Storch, H.: Taking serial correlation into account in tests of the mean, J. Climate, 8, 336-351, 1995. 